\title{
Relationship of Coarse Woody Debris to Arthropod Availability for Red-Cockaded Woodpeckers and Other Bark-Foraging Birds on Loblolly Pine Boles ${ }^{1}$
}

\author{
Scott Horn ${ }^{2}$ and James L. Hanula \\ USDA Forest Service, Southern Research Station, Forestry Sciences Laboratory, 320 Green Street, \\ Athens, Georgia 30602-2044 USA
}

\section{J. Entomol. Sci. 43(2): 153-168 (April 2008)}

Abstract This study determined if short-term removal of coarse woody debris would reduce prey available to red-cockaded woodpeckers (Picoides borealis Vieillot) and other bark-foraging birds at the Savannah River Site in Aiken and Barnwell counties, SC. All coarse woody debris was removed from four 9-ha plots of mature loblolly pine (Pinus taeda L.) in 1997 and again in 1998. We sampled arthropods in coarse woody debris removal and control stands using crawl traps that captured arthropods crawling up tree boles, burlap bands wrapped around trees, and cardboard panels placed on the ground. We captured 27 orders and 172 families of arthropods in crawl traps whereas 20 arthropod orders were observed under burlap bands and cardboard panels. The most abundant insects collected from crawl traps were aphids (Homoptera: Aphididae) and ants (Hymenoptera: Formicidae). The greatest biomass was in the wood cockroaches (Blattaria: Blattellidae), caterpillars (Lepidoptera) in the Family Noctuidae, and adult weevils (Coleoptera: Curculionidae). The most common group observed underneath cardboard panels was Isoptera (termites), and the most common taxon under burlap bands was wood cockroaches. Overall, arthropod abundance and biomass captured in crawl traps was similar in control and removal plots. In contrast, we observed more arthropods under burlap bands (mean \pm SE; 3,021.5 $\pm 348.6, P=0.03)$ and cardboard panels $(3,537.25 \pm 432.4, P=0.04)$ in plots with coarse woody debris compared with burlap bands $(2325 \pm 171.3)$ and cardboard panels $(2439.75 \pm 288.9)$ in plots where coarse woody debris was removed. Regression analyses showed that abundance beneath cardboard panels was positively correlated with abundance beneath burlap bands demonstrating the link between abundance on the ground with that on trees. Our results demonstrate that short-term removal of coarse woody debris from pine forests reduced overall arthropod availability to bark-foraging birds.

Key Words arthropods, bark-foraging birds, bark-gleaning guild, corticulous arthropods, saproxylic

In the southeastern U.S., efforts to increase red-cockaded woodpecker (Picoides borealis Vieillot) populations and improve their habitat have had a major impact on management of public forest lands. These efforts over several decades have resulted in a range-wide population increase from 1991-2003 (Costa 2004). Although its status as an endangered species has focused attention on the red-cockaded woodpecker, a wide variety of other birds also forage in the same types of habitats. Therefore, it is

\footnotetext{
${ }^{1}$ Received 17 September 2007; accepted for publication 04 December 2007.

${ }^{2}$ Address inquiries (email: shorn01@fs.fed.us)
} 
important to understand what factors or forest conditions contribute to sustained prey availability for these woodpeckers and other birds.

Red-cockaded woodpeckers and a variety of other bark-foraging birds use live pine tree trunks as a foraging substrate, but arthropods on tree boles are not restricted to this habitat (Moeed and Mead 1983, Hanula and Franzreb 1998, Hanula and Horn 2004). One component of forest ecosystems that may be important to bark-foraging, as well as a variety of other birds, is large dead wood or coarse woody debris (Hanula and Horn 2004) which includes snags, fallen trees, stumps and decomposing root systems (Harmon et al. 1986). Numerous studies have noted the importance of dead wood to bird diversity and abundance (Davis 1983, Raphael and White 1984, Zarnowitz and Manuwal 1985, Schreiber and deCalesta 1992, Bull and Holthausen 1993, Lanham and Guynn 1993, Lohr et al. 2002), but all dealt with the direct use of dead wood for activities such as feeding, nesting, or roosting. To date, no studies have addressed direct linkages between dead wood and arthropod abundance on live tree boles.

The importance of dead wood to terrestrial insects that spend most of their lives in it is well documented (Speight 1989, Hanula 1996, Grove 2002, Grove and Hanula 2006). However, little information is available on terrestrial arthropods that move readily within forests and only use dead wood as part of their habitat (Irmler et al. 1996, Marra and Edmonds 1998, Andrew et al. 2000, Buddle 2001). Dead wood may be an important part of the habitat for these arthropods, but if they also use live tree trunks they become available to bark-foraging birds. Studies have shown that tree trunks serve as important habitat corridors between the canopy and soil litter layer (Moeed and Mead 1983, Hanula and Franzreb 1998, Majer et al. 2003, Hanula and Horn 2004). Factors that affect this "biological highway" may have profound effects on bark-foraging birds as well as birds foraging in the canopy. As Mariani and Manuwal (1990) suggest, it is important to examine how habitat alterations affect food resource availability.

We studied the interrelationship of coarse woody debris and arthropods found on loblolly pine (Pinus taeda L.) trees. Loblolly pine is the most widely distributed and planted pine species in the southern U.S., occupying over 13.4 million ha (Schultz 1997). Because of its widespread occurrence and importance as a timber species, loblolly pine now serves as the predominant tree available to many bark-foraging birds in the Southeast. The objective of our study was to determine how the absence of coarse woody debris affects the diversity and abundance of arthropods on the boles of live pine trees.

\section{Materials and Methods}

Study area. This study was conducted on the Savannah River Site (SRS) near Aiken, SC, which is operated by the U.S. Department of Energy (DOE). The SRS occupies 80,269 ha located in the upper Atlantic Coastal Plain Physiographic Province. The forested land within the site is managed as a national environmental research park. The site was purchased in 1952 when approximately $67 \%$ of the land was covered by natural forest communities and the remaining land consisted of agriculture and pasture land (Workman and McLeod 1990).

The stands chosen for the study consisted of 40- to 45-yr-old upland loblolly pine plantations. Each plot was 9.3 ha of even-aged loblolly pine, with occasional longleaf or slash pine interspersed. The midstory consisted mostly of hardwood species in- 
cluding mockernut hickory (Carya tomentosa Nutt.), sweetgum (Liquidambar styraciflua L.), blackjack oak (Quercus marilandica Muenchh.), wax myrtle (Myrica cerifera L.), and sassafras (Sassafras albidum Nees). Understory species composition varied somewhat between plots; however, the most commonly encountered species were poison oak (Toxicodendron pubescens $\mathrm{P}$. Mill), trumpet-vine (Campsis radicans L.), Carolina jessamine (Gelsemium sempervirens St.-Hil.), fox grape (Vitis aestivalis Michx.), and beggarticks (Desmodium spp). Less common but notable understory species included southern gooseberry (Vaccinium stamineum L. ), sparkleberry ( $V$. arboretum Marsh.), goldenrod (Solidago spp.), and the invasive, nonnative bicolor lezpedeza (Lezpedeza bicolor Turcz.).

Climate in the region is temperate and mild. Average daily temperatures range from $27^{\circ} \mathrm{C}$ in summer to $9^{\circ} \mathrm{C}$ in the winter with a frost-free period of $240 \mathrm{~d}$ (Sanzone 1995). Average rainfall is $120 \mathrm{~cm}$ per year. From January through December 1998 the site received approx. $174 \mathrm{~cm}$. The largest amount received in one month during this study was in August $1998(47.2 \mathrm{~cm})$ and the lowest rainfall was recorded during October $1998(1.78 \mathrm{~cm})$.

Our study was part of a larger experiment examining coarse woody debris recruitment, rates of decomposition, and the effects of large dead wood removal on various animal groups (McCay et al. 2002). The study was a randomized complete block design consisting of 2 treatments: (1) an undisturbed control, and (2) a total annual removal of all large dead wood greater than $10 \mathrm{~cm}$ diam, including logs and snags. All large dead wood was removed from the plots in January and February 1997, February to March 1998 and March 1999. At the time of our study, control plots contained an average of $6.45-\mathrm{m}^{3} /$ ha of downed logs and $2.04-\mathrm{m}^{3} /$ ha of standing snags and removal plots averaged $0.35-\mathrm{m}^{3} /$ ha and $0.22-\mathrm{m}^{3} /$ ha of logs and snags, respectively (McCay et al. 2002). Plots were square and 9.3 ha in size, but all arthropod sampling was restricted to the central 6 ha of the plots to reduce edge effects.

Arthropod sampling. Arthropods were sampled with crawl traps, burlap bands and cardboard panels. Crawl traps captured arthropods climbing up the tree and were used to determine if coarse woody debris removal affected species richness and abundance. Each crawl trap consisted of an inverted metal funnel cut on the side so the funnel would fit against the tree with the spout pointed upward (Hanula and New 1996). Arthropods crawled up the tree bole, through the funnel spout and into a container attached to the top of the funnel spout. From the container they fell into a specimen cup containing saturated $\mathrm{NaCl}$ solution with $1 \%$ formaldehyde and a drop of soap to reduce surface tension. A $10-\mathrm{cm}$ wide aluminum drift fence, placed around and sealed to the tree with $100 \%$ silicone caulk, prevented most arthropods from bypassing the trap. Crawl traps were placed $2 \mathrm{~m}$ above the ground to facilitate sample collection because trap captures at that position are representative of other locations on the tree bole (Hanula and Franzreb 1998). Fifteen trees within the center 6-ha of each plot were fitted with a crawl trap. The traps were placed in 3 rows of 5 traps $(\sim 50$ $\mathrm{m}$ apart) so they were evenly distributed throughout the study area. Samples were collected monthly from October 1997 to September 1999 and samples from individual traps within a plot were combined into a collective sample for that plot and date.

Samples were sorted into morphologically similar types, placed into $70 \%$ alcohol and identified to morphospecies using a reference collection. Morphospecies have been used successfully to contrast different forest arthropod communities (Oliver and Beattie 1996). The biomass of each morphospecies was estimated by oven-drying 
$\left(40^{\circ} \mathrm{C}\right.$ for $\left.48 \mathrm{~h}\right)$ and weighing all individuals of infrequently collected groups or a representative sample of 30-40 individuals for more common groups.

A second sampling method used burlap bands and cardboard panels (Hanula and Horn 2004) to determine whether coarse woody debris removal affected known prey of the red-cockaded woodpecker. Burlap bands are a nondestructive method of monitoring arthropods on tree boles that harbor arthropods in proportions similar to the red-cockaded woodpecker's diet (Hanula and Horn 2004). Burlap bands consisted of $1 \times 1-\mathrm{m}$ pieces of burlap folded and sewn at the top along the fold, allowing a piece of cotton rope to be threaded through to hold the burlap in place around the tree. Bands were placed around 30 trees within the center 6 -ha of each plot at a height of 1-1.5 m. Ten bands were placed in each of 3 rows so that they were equally distributed throughout the plot. They were checked monthly by slowly untying the rope and lifting the band from the tree to observe arthropods beneath.

Cardboard panels consisted of 4 layers of $0.5 \times 0.75-\mathrm{m}$ corrugated cardboard held together with gray duct tape. Panels were placed 1-3 $\mathrm{m}$ away from each tree with a corresponding burlap band and were used to monitor arthropods on the ground. Sampling consisted of identifying and counting arthropods beneath the cardboard panels. A carry-along reference collection was used to assist field identification. However, if an arthropod could not be identified in the field it was collected, identified later, and incorporated into the collection. Burlap bands and cardboard panels were monitored monthly from July 1998 to September 1999.

Statistical analyses. A paired $t$-test (SAS Institute 1985) was used to test differences between control and removal treatments in abundance and biomass in crawl traps, and abundance beneath burlap bands and cardboard panels. In some cases, we used $\log _{10}(x+1)$ or $\sqrt{ } x+0.5$ transformations to reduce heteroscedasticity (Sokal and Rohlf 1981). We used simple linear regression analyses to examine relationships between arthropods found under burlap bands and cardboard panels.

\section{Results}

We captured $>49,000$ arthropods from 405 genera in 172 families and 27 orders in crawl traps. Table 1 lists some of the most common families that are known or suspected prey of red-cockaded woodpeckers and the number of genera captured. The most abundant orders collected were Homoptera $(23,688)$ consisting primarily of large numbers of aphids, and Hymenoptera $(8,047)$ which were mostly ants. The most diverse orders were Araneae (spiders), Hymenoptera (ants, bees, wasps), and Coleoptera (beetles), respectively. The highest biomasses were found in Coleoptera and Araneae. Morphospecies richness was similar in control plots (167 \pm 8 species/plot, $\bar{X} \pm S E)$ and plots where dead wood was removed (165 \pm 8 species/plot). In addition, the number of rare morphospecies (i.e., $<5$ individuals collected per yr) was also similar in control (62 morphospecies) and removal (56 morphospecies) plots.

Crawl traps on control $(6,361 \pm 893$ arthropods/plot) and removal plots $(6,060 \pm$ 1131 arthropods/plot) caught equal numbers of arthropods and similar amounts of arthropod biomass (control $=14.66 \pm 1.67 \mathrm{~g} /$ plot versus dead wood removal $=12.58$ $\pm 0.49 \mathrm{~g} /$ plot; $P=0.25$ ). No arthropod order was captured in significantly greater numbers or biomass. However, the mean biomass of the spider family Salticidae (jumping spiders) was higher in control plots $(0.39 \pm 0.07 \mathrm{~g} / \mathrm{plot})$ than in removal plots $(0.25 \pm 0.04 \mathrm{~g} / \mathrm{plot})(P=0.03)$. In addition, the mean biomass of Araneidae (orbweaving spiders) was also higher in control plots $(0.27 \pm 0.07 \mathrm{~g} / \mathrm{plot})$ compared with 
removal plots $(0.12 \pm 0.06 \mathrm{~g} / \mathrm{plot})(P=0.05)$. Two spiders, Neoscona sp. (Araneidae) $(0.23 \pm 0.04 \mathrm{~g} /$ control plot and $0.10 \pm 0.05 \mathrm{~g} /$ removal plot; $P=0.03)$ and Phidippus sp. (Salticidae) $(0.35 \pm 0.06 \mathrm{~g} / \mathrm{control}$ plot and $0.22 \pm 0.04 \mathrm{~g} / \mathrm{removal}$ plot; $P=0.03)$ had significantly higher biomass on control plots and accounted for most of the biomass in those families.

We observed more than 45,000 arthropods beneath burlap bands and cardboard panels representing 20 orders and 82 families (Table 2). The most abundant order was Isoptera $(17,425)$ beneath cardboard panels, followed by Blattaria $(12,367)$ beneath cardboard and burlap. The latter were primarily wood cockroaches in the genus Parcoblatta. The most diverse orders were Coleoptera and Araneae. Regression analyses revealed positive correlations between abundance under burlap bands and abundance under adjacent cardboard panels for a wide variety of arthropod groups (Table 3).

Overall, we observed more arthropods beneath cardboard panels and burlap bands in control plots $(P=0.02)$ where dead wood was left undisturbed (Fig. 1). We removed termites from the analysis because they were attracted to and fed on the cardboard panels. Even with termites removed, control plots had greater numbers of arthropods (Fig. 1, $P=0.04$ ). A number of arthropod taxa were found in slightly higher numbers under burlap bands and cardboard panels on control plots, but only the Hemiptera were significantly higher (Fig. 2). However, this general trend of higher numbers in control plots resulted in the overall arthropod abundance being significantly different as mentioned above. Analyses of the various genera showed only Crematogaster spp. ants occurred in significantly greater numbers in control plots (567 \pm 82 ants/plot) compared with dead wood removal plots $(217 \pm 56$ ants/plot) $(P=0.04)$. Conversely, harvestmen (Order Opiliones) were the only group observed in greater numbers in dead wood removal plots $(7 \pm 2.1$ individuals/plot) versus control plots $(3 \pm 1.9$ individuals/plot) $(P=0.01)$, although the number collected was small.

Burlap bands and cardboard panels analyzed separately had more arthropods in control plots (burlap bands, $P=0.03$; cardboard panels, $P=0.04$ ). Hemiptera were more abundant beneath burlap bands $(441 \pm 91$ individuals/plot; $P=0.03)$ and cardboard panels ( $14 \pm 4.2$ individuals/plot; $P=0.02$ ) in control plots compared with burlap bands (286 \pm 42 individuals/plot) and cardboard panels $(5 \pm 1.8$ individuals/plot) in dead wood removal plots. Members of the Family Formicidae were more abundant in control plots $(391 \pm 95$ individuals/plot) compared with removal plots $(181 \pm 27$ individuals/plot) beneath burlap bands only $(P=0.05)$.

Overall abundance of arthropods beneath burlap bands was relatively high throughout the year whereas numbers observed beneath cardboard panels declined in the winter months from November through March. Conversely, arthropod abundance was greatest beneath burlap bands on tree boles during the same period (Fig. $3)$. We found wood cockroaches were relatively abundant throughout the year beneath burlap bands, whereas ants were least abundant in the fall and winter but their number gradually increased from March through September.

\section{Discussion}

Our findings provide baseline information regarding arthropods occurring on live loblolly pine tree boles, the linkage between tree boles and the soil/litter layer, and their relative abundance in the absence of coarse woody debris. This information is relevant to ornithologists and wildlife biologists interested in the feeding habitats and 
Table 1. Total number, biomass, and number of genera of arthropod groups known or suspected to be prey of the red-cockaded woodpecker that were captured in crawl traps. Traps were open during the period October 1997 to September 1999 on loblolly pine tree boles at the Savannah River Site, SC

\begin{tabular}{|c|c|c|c|c|}
\hline Order (common name) & Family & $\begin{array}{l}\text { No. of } \\
\text { Genera }\end{array}$ & $\begin{array}{c}\text { Number } \\
\text { caught }\end{array}$ & $\begin{array}{c}\text { Biomass } \\
\text { (g) }\end{array}$ \\
\hline \multirow[t]{22}{*}{ Araneae (spiders) } & Anyphaenidae & 4 & 39 & 0.0657 \\
\hline & Araneidae & 9 & 53 & 1.5314 \\
\hline & Clubionidae & 7 & 399 & 0.5947 \\
\hline & Corinnidae & 2 & 114 & 0.0383 \\
\hline & Ctenizidae & 1 & 1 & 0.0003 \\
\hline & Dictynidae & 2 & 409 & 0.4014 \\
\hline & Gnaphosidae & 9 & 774 & 0.9384 \\
\hline & Hahniidae & 1 & 33 & 0.0095 \\
\hline & Linyphiidae & 15 & 2259 & 0.6136 \\
\hline & Lycosidae & 4 & 586 & 1.8908 \\
\hline & Lyssomanidae & 1 & 31 & 0.0194 \\
\hline & Mimetidae & 1 & 79 & 0.0429 \\
\hline & Oxyopidae & 2 & 11 & 0.0258 \\
\hline & Philodromidae & 2 & 53 & 0.1494 \\
\hline & Pholcidae & 1 & 1 & 0.0001 \\
\hline & Pisauridae & 2 & 21 & 0.5893 \\
\hline & Salticidae & 11 & 522 & 2.5681 \\
\hline & Segestriidae & 1 & 17 & 0.0755 \\
\hline & Tetragnathidae & 1 & 10 & 0.01 \\
\hline & Theridiidae & 13 & 1077 & 1.3087 \\
\hline & Uloboridae & 1 & 2 & 0.0003 \\
\hline & Zoridae & 1 & 2 & 0.002 \\
\hline Blattaria (cockroaches) & Blatellidae & 3 & 2845 & 12.2952 \\
\hline \multirow[t]{6}{*}{ Coleoptera (beetles) } & Unknown & - & 9 & 0.0008 \\
\hline & Alleculidae & 2 & 55 & 0.3297 \\
\hline & Anobiidae & 2 & 3 & 0.0171 \\
\hline & Anthicidae & 1 & 1 & 0.0001 \\
\hline & Anthribidae & 1 & 2 & 0.0042 \\
\hline & Cantharidae & 1 & 9 & 0.006 \\
\hline
\end{tabular}


Table 1. Continued.

\begin{tabular}{|c|c|c|c|c|}
\hline \multirow[t]{35}{*}{ Coleoptera (beetles) } & Carabidae & 4 & 27 & 0.2886 \\
\hline & Cebrionidae & 1 & 1 & 0.005 \\
\hline & Cerambycidae & 2 & 3 & 0.1184 \\
\hline & Chrysomelidae & 5 & 14 & 0.1377 \\
\hline & Cleridae & 1 & 14 & 0.1173 \\
\hline & Coccinellidae & 7 & 32 & 0.0304 \\
\hline & Colydiidae & 3 & 3 & 0.0012 \\
\hline & Corylophidae & 3 & 28 & 0.0044 \\
\hline & Crytophagidae & 2 & 13 & 0.0038 \\
\hline & Cucujidae & 2 & 3 & 0.0075 \\
\hline & Curculionidae & 11 & 266 & 9.9125 \\
\hline & Dytiscidae & 1 & 1 & 0.0023 \\
\hline & Elateridae & 13 & 139 & 2.6073 \\
\hline & Endomycidae & 1 & 5 & 0.0152 \\
\hline & Hydrophilidae & 1 & 7 & 0.0012 \\
\hline & Lampyridae & 1 & 2 & 0.0064 \\
\hline & Leptodiridae & 1 & 1 & 0.0002 \\
\hline & Lycidae & 1 & 1 & 0.0009 \\
\hline & Melandryidae & 3 & 4 & 0.0044 \\
\hline & Meloidae & 1 & 1 & 0.1367 \\
\hline & Melyridae & 2 & 7 & 0.0016 \\
\hline & Micromathidae & 1 & 1 & 0.0001 \\
\hline & Rhizophagidae & 1 & 1 & 0.003 \\
\hline & Mordellidae & 2 & 4 & 0.0041 \\
\hline & Mycetophagidae & 3 & 23 & 0.0082 \\
\hline & Nitidulidae & 4 & 19 & 0.0159 \\
\hline & Oedemeridae & 1 & 1 & 0.0017 \\
\hline & Ptinidae & 1 & 1 & 0.0001 \\
\hline & Scarabaeidae & 4 & 45 & 3.7561 \\
\hline & Scolytidae & 4 & 56 & 0.0162 \\
\hline & Scydmaenidae & 1 & 3 & 0.0001 \\
\hline & Staphylinidae & 1 & 123 & 0.0197 \\
\hline & Tenebrionidae & 2 & 89 & 1.555 \\
\hline & Throscidae & 1 & 26 & 0.0103 \\
\hline & Trogossitidae & 1 & 1 & 0.0013 \\
\hline
\end{tabular}


Table 1. Continued.

\begin{tabular}{|c|c|c|c|c|}
\hline Order (common name) & Family & $\begin{array}{l}\text { No. of } \\
\text { Genera }\end{array}$ & $\begin{array}{c}\text { Number } \\
\text { caught }\end{array}$ & $\begin{array}{c}\text { Biomass } \\
\text { (g) }\end{array}$ \\
\hline Hymenoptera (ants only) & Formicidae & 19 & 6706 & 5.4701 \\
\hline \multirow[t]{11}{*}{ Lepidoptera (moths) } & Arctiidae & 1 & 8 & 0.2063 \\
\hline & Gelechidae & 1 & 62 & 0.0219 \\
\hline & Geometridae & 1 & 625 & 0.842 \\
\hline & Lasiocampidae & 1 & 3 & 0.0399 \\
\hline & Lycaenidae & 1 & 1 & 0.0115 \\
\hline & Noctuidae & 2 & 341 & 13.3235 \\
\hline & Notodontidae & 1 & 12 & 0.0302 \\
\hline & Oecophoridae & 1 & 3 & 0.014 \\
\hline & Psychidae & 1 & 6 & 0.0262 \\
\hline & Pyralidae & 1 & 18 & 0.0477 \\
\hline & Sphingidae & 2 & 24 & 1.1997 \\
\hline Microcoryphia (bristletails) & Machilidae & 1 & 568 & 0.5114 \\
\hline Orthoptera (grasshoppers & Unknown & 1 & 2 & 0.0011 \\
\hline \multirow[t]{3}{*}{ and crickets) } & Acrididae & 2 & 14 & 0.3191 \\
\hline & Gryllidae & 4 & 214 & 0.5481 \\
\hline & Tettigoniidae & 5 & 63 & 0.9492 \\
\hline Scolopendromorpha & Cryptopididae & 1 & 5 & 0.1667 \\
\hline (centipedes) & Scolopendridae & 1 & 20 & 1.512 \\
\hline Thysanura (silverfish) & Lepismatidae & 1 & 11 & 0.0041 \\
\hline
\end{tabular}

forage availability of bark-foraging birds commonly found in loblolly pine forests. Red-cockaded woodpeckers readily forage on loblolly pine trees but were not present in our study areas. The most frequently observed birds foraging in our research areas were: red-headed woodpeckers (Melanerpes erythrocephalus L.), red-bellied woodpeckers (Melanerpes carolinus L.), northern flickers (Colaptes auratus L.), pileated woodpeckers (Dryocopus pileatus L.), and brown-headed nuthatches (Sitta pusilla Latham). Other species that glean on loblolly pine bark but take advantage of a variety of other substrates were chickadees (Poecile carolinensis Audubon), titmice (Baeolophus bicolor L.), and pine warblers (Dendroica pinus Wilson) (J. Kilgo, pers. comm.).

We collected many of the same common species described by Hanula and Franzreb (1998) and Horn and Hanula (2002a) on longleaf pine, showing that the arthropod community on pines is similar regardless of tree species. Removal of coarse woody debris did not reduce overall arthropod diversity, abundance or biomass captured in crawl traps. The only differences noted were for the 2 spider families Saltici- 
Table 2. Total genera and number of individuals observed for each arthropod order found beneath burlap bands and cardboard panels from July 1998 until September 1999 in loblolly pine stands on the Savannah River Site near Aiken, SC

\begin{tabular}{lcc}
\hline \hline \multicolumn{1}{c}{ Order } & Number of Genera & Number Observed \\
\hline Araneae & 27 & 2753 \\
Blattaria & 3 & 12367 \\
Callipodida & 1 & 101 \\
Coleoptera & 53 & 3867 \\
Diptera & 1 & 1 \\
Geophilomorpha & 1 & 34 \\
Hemiptera & 18 & 2938 \\
Hymenoptera & 10 & 3861 \\
Isoptera & 1 & 17425 \\
Lepidoptera & 6 & 30 \\
Lithobiomorpha & 1 & 84 \\
Mantodea & 1 & 2 \\
Microcoryphia & 1 & 7 \\
Neuroptera & 3 & 46 \\
Opiliones & 1 & 38 \\
Orthoptera & 6 & 189 \\
Polydesmida & 1 & 18 \\
Scolopendromorpha & 2 & 266 \\
Thysanura & 1 & 1677 \\
\hline
\end{tabular}

dae and Araneidae, primarily because of the genera Phidippus and Neoscona, respectively. Because so few families or genera were significant, it is difficult to know if these differences are simple artifacts of the large number of analyses that we conducted. Our study was conducted over a 2-yr period, and coarse woody debris removal started $1 \mathrm{yr}$ prior to sampling. Therefore, the effect of dead wood removal on overall arthropod diversity and abundance, as indicated by crawl traps, may become more evident over a longer period of time. For example, many arthropods have one generation per year so their populations may decrease gradually over time in the absence of dead wood.

Crawl traps provide a passive method of collecting many arthropod groups crawling on tree boles and have been used successfully to study the overall arthropod community associated with tree boles (Moeed and Mead 1983, Hanula and Franzreb 1998, Hanula and New 1996, Hanula et al. 2000a). However, previous studies have shown that red-cockaded woodpeckers select relatively few, common arthropods 
Table 3. Regression analyses of arthropod abundance underneath burlap bands $(x)$ and cardboard panels $(y)^{*}$

\begin{tabular}{|c|c|c|c|c|c|c|}
\hline \multirow[b]{2}{*}{ Regression Model } & \multirow[b]{2}{*}{$\mathrm{R}^{2}$} & \multirow[b]{2}{*}{ F-value } & \multicolumn{2}{|c|}{$P$} & \multicolumn{2}{|c|}{ SE } \\
\hline & & & $b_{0}$ & $b_{1}$ & $b_{1}$ & $b_{0}$ \\
\hline yAraneae $=0.37+0.02$ burlap & 0.63 & 390.19 & 0.0001 & 0.0001 & 0.05 & 0.0011 \\
\hline yCallipoda $=1.21+1.03$ burlap & 0.76 & 98.53 & 0.0003 & 0.0001 & 0.3 & 0.1 \\
\hline yColeoptera $=0.15+0.02$ burlap & 0.62 & 296.41 & 0.03 & 0.0001 & 0.07 & 0.0008 \\
\hline yHemiptera $=0.11+0.02$ burlap & 0.31 & 93.87 & 0.31 & 0.0001 & 0.10 & 0.002 \\
\hline yOrthoptera $=0.8+0.78$ burlap & 0.58 & 109.05 & 0.0001 & 0.0001 & 0.2 & 0.07 \\
\hline $\begin{array}{c}\text { yScolopendromorpha }= \\
0.93+0.26 \text { burlap }\end{array}$ & 0.34 & 51.70 & 0.0001 & 0.0001 & 0.12 & 0.04 \\
\hline yAcrididae $=-0.14+0.10$ burlap & 0.68 & 40.97 & 0.0028 & 0.0001 & 0.04 & 0.02 \\
\hline $\begin{array}{l}\text { yCasiopetalidae }=1.21+ \\
1.03 \text { burlap }\end{array}$ & 0.76 & 98.53 & 0.0003 & 0.0001 & 0.3 & 0.1 \\
\hline yLycosidae $=0.41+0.06$ burlap & 0.32 & 56.47 & 0.0001 & 0.0001 & 0.08 & 0.008 \\
\hline $\begin{array}{l}\text { yPentatomidae }=-0.17+ \\
\text { 0.09burlap }\end{array}$ & 0.32 & 45.82 & 0.39 & 0.0001 & 0.20 & 0.01 \\
\hline $\begin{array}{l}\text { yThomisidae }=-0.04+ \\
0.02 \text { burlap }\end{array}$ & 0.37 & 23.21 & 0.24 & 0.0001 & 0.03 & 0.005 \\
\hline
\end{tabular}

* Includes arthropod groups with $\mathrm{R}^{2}>0.30$.

(Beal 1911, Harlow and Lennartz 1977, Hanula and Franzreb 1995, Hess and James 1998, Hanula and Engstrom 2000, Hanula et al. 2000a,b) and that prey selection is related to prey availability (Hanula and Horn 2004). Pechacek and Kristin (2004) found that three-toed woodpeckers (Picoides tridactylus) also consistently selected a narrow range of prey (spiders and beetle larvae) even though other groups were available. Likewise, brown creepers (Certhia americana) (Mariani and Manuwal 1990) and Eurasian treecreepers (Certhia familiaris) (Jantti et al. 2001) seemed to preferentially select common groups such as spiders.

In contrast to crawl traps that capture arthropods continuously, burlap bands provide a nondestructive method of assessing prey available for use by bark-foraging birds when birds are actively foraging. Burlap bands also sample arthropods in approximately the same proportions as they were selected as prey by red-cockaded woodpeckers (Hanula and Horn 2004). Likewise three-toed woodpeckers in Germany selected spiders in comparable numbers to their availability on trees (Pechacek and Kristin 2004). It is highly likely that other bark-foraging birds choose prey based on availability.

We found significant positive correlations of the arthropod numbers observed beneath cardboard panels on the ground and beneath burlap on nearby trees for a large number of arthropod groups. These results support previous studies (Hanula and Franzreb 1998) showing that the bark of pine trees is an "open system" with ready 


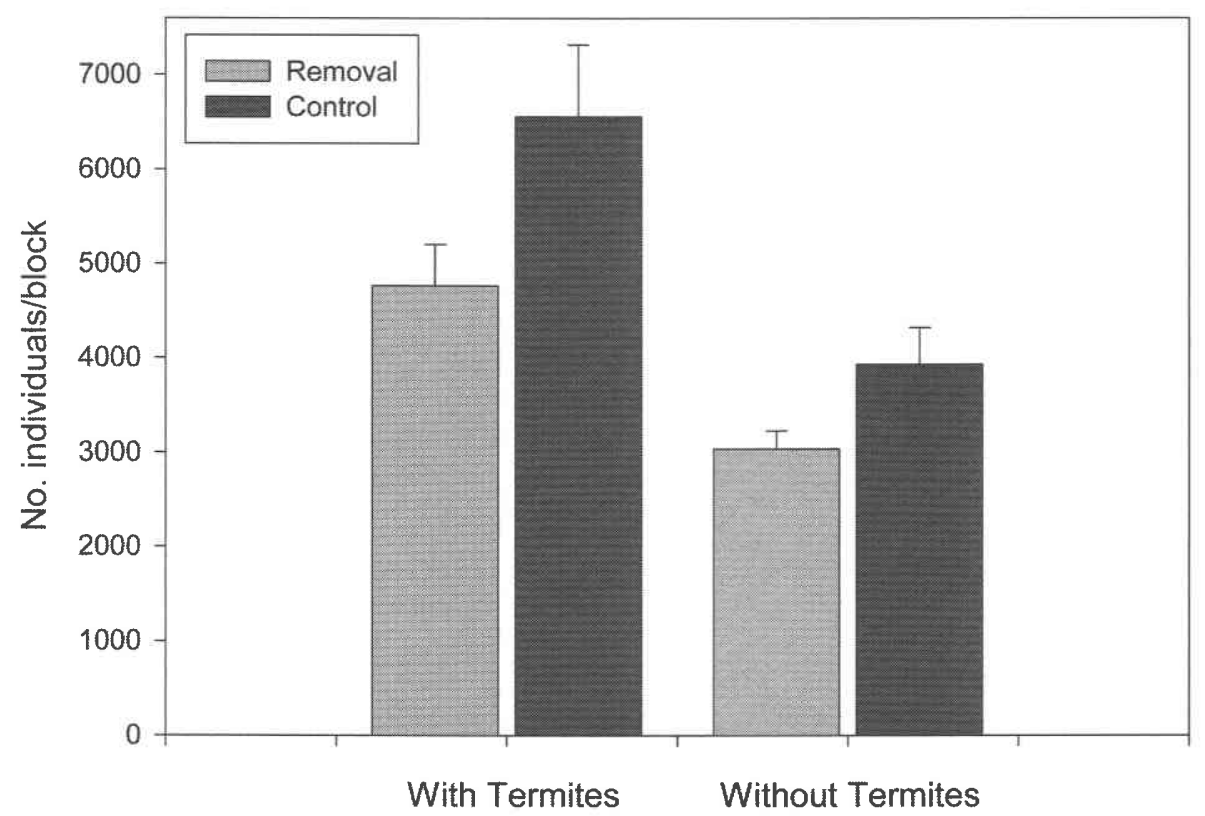

Fig. 1. Mean ( \pm SE) arthropods/block observed underneath burlap bands and cardboard panels in control and removal plots. Traps were monitored from July 1998 to September 1999. Means are significantly different for overall arthropods $(P=0.02)$ according to a paired $t$-test. Even with termites removed the difference was significant $(P=0.04)$.

exchange of arthropods from the soil/litter layer to the bark surface, but they also show that arthropod abundance on tree boles is directly related to the abundance of those arthropods occurring on the ground in close proximity to the tree.

Cardboard panels on the ground had large numbers of termites. Because termites were attracted to and fed upon the cardboard and were not found on tree boles in any trap, we removed them from the analyses which did not affect the results. Even with termites excluded from the analyses removal of dead wood resulted in a reduction in the overall numbers of arthropods found beneath cardboard panels and burlap bands.

Wood cockroaches in the genus Parcoblatta were the next most abundant group. We were especially interested in monitoring changes in wood cockroach abundance because they constitute a high proportion of the woodpecker's diet on the Savannah River Site and elsewhere (Hanula and Franzreb 1995, Hanula and Engstrom 2000, Hanula et al. 2000b). The short-term removal of dead wood in this study had no effect on the abundance of wood cockroaches despite the clear association of these insects with both standing dead trees and logs lying on the ground (Horn and Hanula 2002). It is unclear whether dead wood is an essential habitat for cockroaches, but removal of coarse woody debris over 2 yrs did not affect their populations.

In general, most arthropod orders were lower in number on coarse woody debris removal plots, but only Hemiptera were significantly reduced. These data suggest that 


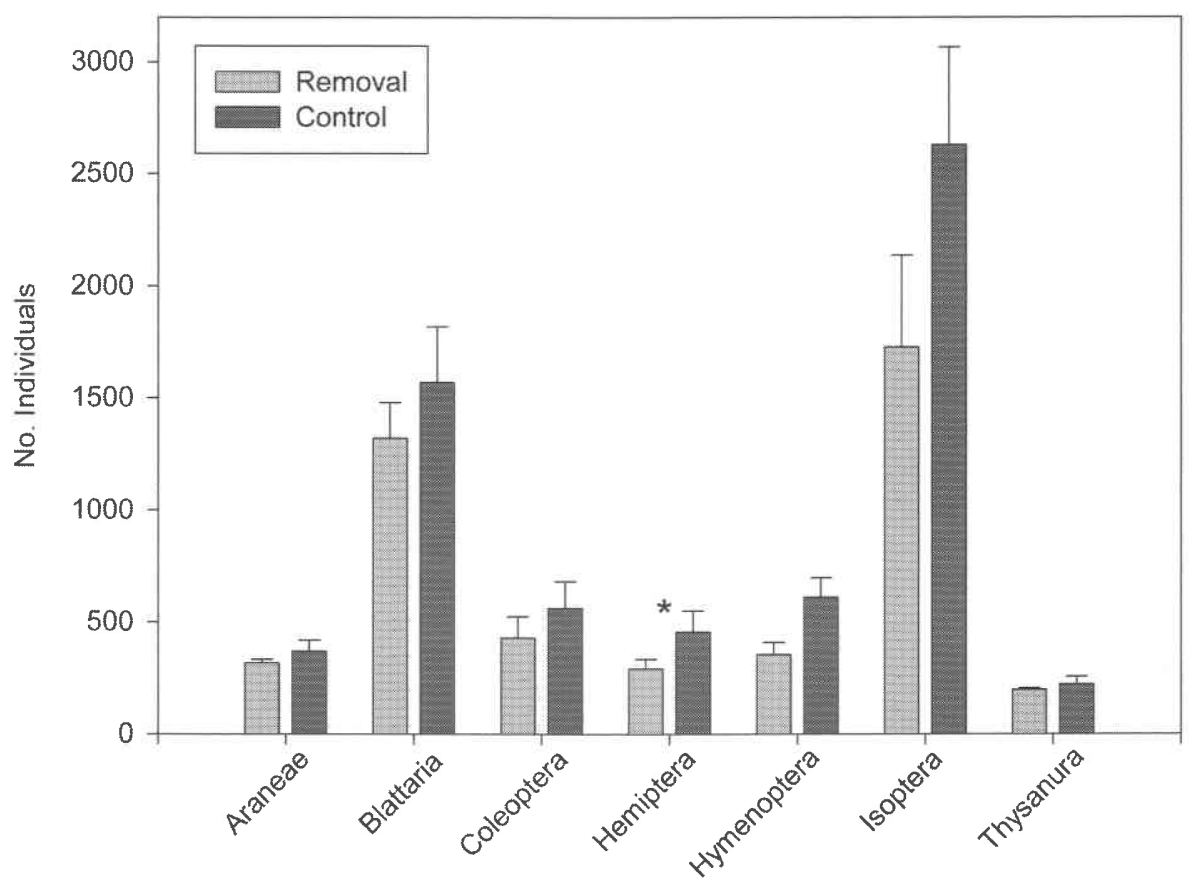

Arthropod Order

Fig. 2. Comparison of arthropod abundance in control and removal plots of the most commonly collected orders beneath burlap bands and cardboard panels. $\left({ }^{*}\right)$ Denotes that the relationship was significant $(P=0.05)$ according to a paired t-test.

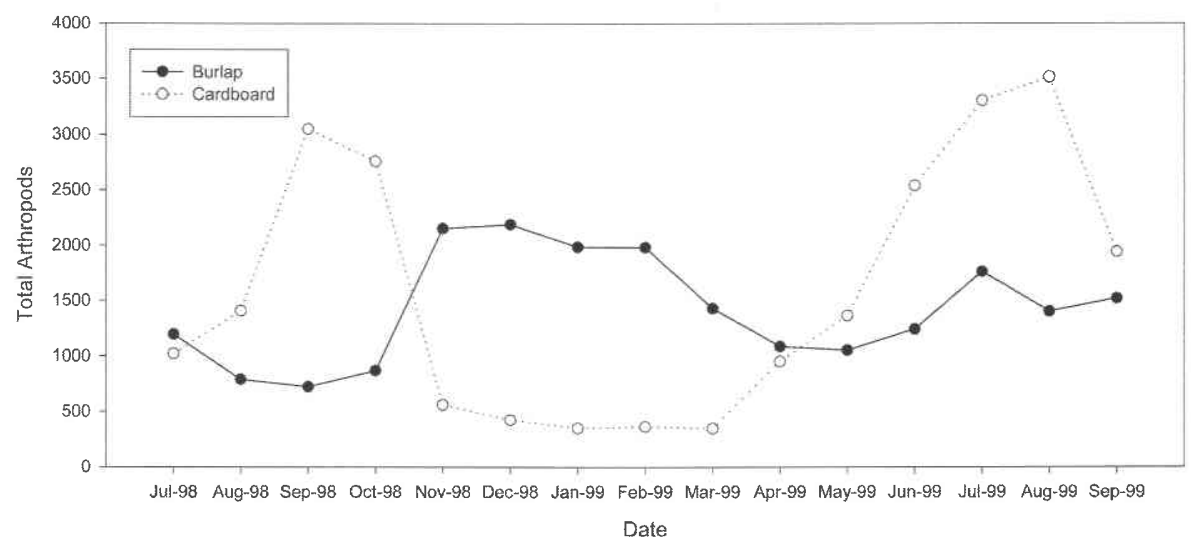

Fig. 3. Seasonal abundance of total arthropods underneath burlap bands and cardboard panels combined for coarse woody debris control and removal plots from July 1998 to September 1999. 
the removal of dead wood from pine forests affects a lot of groups in small amounts resulting in a cumulative reduction of available prey. Whether this was due to removal of the arthropods with the dead wood or to a loss of habitat and subsequent population declines is unknown.

Crematogaster ants were significantly more abundant in control plots. Hess and James (1998) found that prescribed burning reduced the number of Crematogaster ants in longleaf pine stands, and New and Hanula (1998) found that summer burning reduced ant and spider biomass on pine tree boles when compared with winter burns conducted the same year. These results may be due in part to removal of woody debris through burning. The role coarse woody debris might play in the biology of Crematogaster spp. ants is not clear (Hahn and Tschinkel 1997, Tschinkel and Hess 1999, Tschinkel 2002). Hahn and Tschinkel (1997) found that queens preferentially established colonies in beetle galleries in dead branches of the longleaf pine saplings they studied. Colonies also have been found in dead branches of mature longleaf pines (Hanula and Franzreb 1998) and pine cones killed by coneworms, Dioryctria spp. (Hanula, unpubl. data). Their association with dead wood in live trees is clear but whether they also use insect galleries in dead trees is not known. Likewise, it is unclear how removal of coarse woody debris would affect abundance of Crematogaster spp. on live trees.

Seasonal trends in arthropod availability on bark are important for identifying times when food might be limited (Hanula et al. 2000a). Beyer et al. (1996) hypothesized that in years of good arthropod production red-cockaded woodpecker reproduce successfully, and in years of low arthropod production red-cockaded woodpeckers with poorer foraging habitat may be negatively affected. For example, Schaefer et al. (2004) found that red-cockaded woodpecker foraging in an area with large numbers of dying pines benefited from the increase in prey biomass they obtained by foraging on the dead trees.

Skorupa and McFarlane (1976) predicted that winter would be a time of limited arthropod availability and summer would be a time of abundance. Likewise, Hooper (1996) stated that winter would be a time of arthropod scarcity. In contrast, Hanula and Franzreb (1998) and Hanula et al. (2000a) found that arthropod abundance on pine tree boles was lowest during the summer and greatest in the winter. Likewise, we found overall arthropod abundance increased during winter under burlap bands on trees, and it was somewhat lower in spring and summer. In contrast, arthropod abundance beneath cardboard panels placed on the ground was greatest in summer. It is not clear whether seasonal declines in prey availability affect red-cockaded woodpecker survival.

Burlap bands are a simple and effective way to monitor arthropods readily available to bark-foraging birds. Previous studies showed that wood cockroaches comprise $50 \%$ or more of the red-cockaded woodpecker nestling diet in a variety of locations and pine habitats (Hanula and Franzreb 1995, Hanula and Engstrom 2000, Hanula et al. 2000b). Crawl traps collected more than 2800 wood cockroaches over the course of 24 months. Observations beneath burlap bands and cardboard panels yielded $>12,000$ wood cockroaches in 15 months demonstrating the utility of these techniques at collecting and observing this and other common arthropod groups.

Southern forests are typically managed without considering the role of dead and dying trees to the overall food web. Our data suggest that allowing natural inputs of coarse woody debris and maintaining diverse decay stages will ensure sufficient habitat for arthropod communities occurring on loblolly pine. Future studies should 
evaluate how the arthropod community changes in coarse woody debris over time, and how that change contributes to the overall food web.

\section{Acknowledgments}

The authors thank Todd Kuntz for technical assistance throughout the project and also thank Kelly Horn, Mike Slice, Nicole Rankine, Mary Williams, Arthur Phalo, and Mark Rubenstein for work in the lab. We also thank Lee Reynolds and James Pitts for identification of many lesserknown arthropod taxa and John Kilgo for information on bird species. This study was funded by the Department of Energy, Savannah River Site, and the USDA Forest Service, Savannah River Site Natural Resources Management and Research Institute.

\section{References Cited}

Andrew, N., L. Rodgerson and A. York. 2000. Frequent fuel-reduction burning: the role of logs and associated leaf litter in the conservation of ant biodiversity. Austral Ecol. 25: 99-107.

Beal, F. E. L. 1911. Food of the woodpeckers of the United States. U.S. Department of Agriculture. Biological Survey Bulletin 37.

Beyer Jr., D. E., R. Costa, R. G. Hooper and C. A. Hess. 1996. Habitat quality and reproduction of red-cockaded woodpecker groups in Florida. J. Wildl. Manage. 60: 826-835.

Buddle, C. M. 2001. Spiders (Araneae) associated with downed woody material in a deciduous forest in central Alberta, Canada. Agric. For. Entomol. 3: 241-251.

Bull, E. L. and R. S. Holthausen. 1993. Habitat use and management of pileated woodpeckers in northeastern Oregon. J. Wildl. Manage. 57: 335-345.

Costa, R. 2004. State of the red-cockaded woodpecker world: highlights of the previous decade (1992- 2002), Pp. 39-46. In R. Costa and S.J. Daniels (eds.), Red-cockaded Woodpecker: Road to Recovery. Hancock House Publ., Blaine, WA.

Davis, J. W. 1983. Snags are for wildlife. Gen. Tech. Rep. RM-99. U.S. For. Serv., Rocky Mountain Research Station, Flagstaff, AR.

Grove, S. J. 2002. Saproxylic insect ecology and the sustainable management of forests. Annu. Rev. Ecol. Syst. 33: 1-23.

Grove, S. J. and J. L. Hanula. 2006. Insect biodiversity and dead wood: proceedings of a symposium for the $22^{\text {nd }}$ International Congress of Entomology. USDA Forest Service, Gen. Tech. Rep. SRS-93, Asheville, NC.

Hahn, D. A. and W. R. Tschinkel. 1997. Settlement and distribution of colony-founding queens of the arboreal ant, Crematogaster ashmeadi, in a long-leaf pine forest. Ins. Soc. 44: 323336.

Hanula, J. L. 1996. Relationship of wood-feeding insects and coarse woody debris, Pp. 55-81. In J.W. McMinn and D.A. Crossley Jr. (eds.), Biodiversity and Coarse Woody Debris in Southern Forests. USDA For. Serv., Gen. Tech. Rep. SE-94.

Hanula, J. L. and F. T. Engstrom. 2000. Comparison of red-cockaded woodpecker (Picoides borealis) nestling diet in old-growth and old-field longleaf pine (Pinus palustris) habitats. Am. Midl. Nat. 144: 370-376.

Hanula, J. L. and K. E. Franzreb. 1995. Diet of nestling red-cockaded woodpeckers in the Upper Coastal Plain of South Carolina. Wilson Bull. 107: 485-495.

1998. Source, distribution, and abundance of macroarthropods on the bark of longleaf pine: potential prey of the red-cockaded woodpecker. For. Ecol. Manage. 102: 89-102.

Hanula, J. L., K. E. Franzreb and W. D. Pepper. 2000a. Longleaf pine characteristics associated with arthropods available for red-cockaded woodpeckers. J. Wildl. Manage. 64: 60-70.

Hanula, J. L. and S. Horn. 2004. Availability and abundance of prey for the red-cockaded woodpecker, Pp. 605-617. In R. Costa and S. J. Daniels (eds.), Red-cockaded Woodpecker: Road to Recovery. Hancock House Publ, Blaine, Washington. 
Hanula, J. L., D. Lipscomb, K. E. Franzreb and S. C. Loeb. 2000b. Diet of nestling redcockaded woodpeckers at three locations. J. of Field Ornithol. 71: 126-134.

Hanula, J. L. and K. C. New. 1996. A trap for capturing arthropods crawling up tree boles. Research Note SRS-3, USDA Forest Service, Southern Research Station, Asheville, NC, 7 pp.

Harlow, R. F. and M. R. Lennartz. 1977. Foods of nestling red-cockaded woodpeckers in coastal South Carolina. Auk 94: 376-377.

Harmon, M. E., J. F. Franklin, F. J. Swanson, P. Sollins, S. V. Gregory, J. D. Lattin, N. H. Anderson, S. P. Cline, N. G. Aumen, J. R. Sedell, G. W. Jr. Lienkaemper, K. Cromack and K. W. Cummins. 1986. Ecology of coarse woody debris in temperate ecosystems. Adv. Ecol. Res. 15: 133-302.

Hess, C. A. and F. C. James. 1998. Diet of the red-cockaded woodpecker in the Apalachicola National Forest. J. Wildl. Manage. 62: 509-517.

Hooper, R. G. 1996. Arthropod biomass in winter and the age of longleaf pines. For. Ecol. Manage. 82: 115-131.

Horn, S. and J. L. Hanula. 2002a. Comparison of arthropod prey of red-cockaded woodpeckers on the boles of longleaf and loblolly pines. Wildl. Soc. Bull. 30: 131-138.

2002b. Life history and habitat associations of the broad wood cockroach, Parcoblatta lata (Blattaria: Blattellidae) and other native cockroaches in the coastal plain of South Carolina. Ann. Entomol. Soc. Am. 95: 665-671.

Irmler, U., K. Heller and J. Warning. 1996. Age and tree species as factors influencing the populations of insects living in dead wood (Coleoptera, Diptera:Sciaridae, Mycetophilidae). Pedobiologia (Jena) 40: 134-148.

Jantti, A., T. Aho, H. Hakkarainen, M. Kuitunen and J. Suhonen. 2001. Prey depletion by the foraging of the Eurasian treecreeper, Certhia familiaris, on tree-trunk arthropods. Oecologia 128: $488-491$.

Lanham, J. D. and D. C. Guynn. 1993. Influences of coarse woody debris in southern forests, Pp. 101- 107. In J.W. McMinn and D.A. Crossley (eds.), Biodiversity and Coarse Woody Debris in Southern Forests. Gen. Tech. Rep. SE-94. U.S. For. Serv., Southern Res. Station, Asheville, North Carolina.

Lohr, S. M., S. A. Gauthreaux and J. C. Kilgo. 2002. Importance of coarse woody debris to avian communities in loblolly pine forests. Cons. Biol. 16: 767-777.

Majer, J. D., H. F. Recher, R. Graham and R. Gupta. 2003. Trunk invertebrate faunas of Western Australian forests and woodlands: influence of tree species and season. Austral Ecol. 28: 629-641.

Mariani, J. M. and D. A. Manuwal. 1990. Factors influencing brown creeper (Certha americana) abundance patterns in the southern Washington Cascade range. Studies Avian Biol. 13: 53-57.

Marra, J. L. and R. L. Edmonds. 1998. Effects of coarse woody debris and soil depth on the density and diversity of soil invertebrates on clearcut and forested sites on the Olympic Penninsula, Washington. Environ. Entomol. 27: 1111-1124.

McCay, T. S., J. L. Hanula, S. C. Loeb, S. M. Lohr, J. W. McMinn and B. D. Wright-Miley. 2002. The role of coarse woody debris in Southeastern pine forests: preliminary results from a large-scale experiment. USDA Gen. Tech. Rep. PSW-GTR-181.

Moeed, A. and M. J. Mead. 1983. Invertebrate fauna of four tree species in Orongorongo Valley New Zealand, as revealed by trunk traps. N. Z. J. Ecol. 6: 39-53.

New, K. C. and J. L. Hanula. 1998. Effect of time elapsed after prescribed burning in longleaf pine stands on potential prey of the red-cockaded woodpecker. Southern J. Appl. For. 22: 175-182.

Oliver, I. and A. J. Beattie. 1996. Designing cost-effective invertebrate sampling methods for rapid assessment of biodiversity. Ecol. Soc. Am., Washington, DC.

Pechacek, P. and A. Kristin. 2004. Comparative diets of adult and young three-toed woodpeckers in a European alpine forest community. J. Wildl. Manage. 68: 683-693. 
Raphael, M. G. and M. White. 1984. Use of snags by cavity-nesting birds in the Sierra Nevada. Wildlife Monogr. 86: 1-66.

Sanzone, D. M. 1995. Macroarthropods associated with coarse woody debris: factors influencing abundance and diversity patterns. M.S. Thesis, Univ. Georgia, Athens, GA.

SAS Institute. 1985. SAS guide for personal computers. Version 6 ed., SAS Institute, Cary, NC. $378 \mathrm{pp}$.

Schaefer, R. R., R. N. Conner, D. C. Rudolph and D. Saenz. 2004. Red-cockaded woodpecker nestling provisioning and reproduction in two different pine habitats. Wilson Bull. 116: 31-40.

Schreiber, B. and D. S. deCalesta. 1992. The relationship between cavity-nesting birds and snags on clearcuts in western Oregon. For. Ecol. Manage. 50: 299-316.

Schultz, R. P. 1997. Loblolly pine: ecology and culture of loblolly pine. Agricultural handbook 713. U.S. For. Serv., Southern For. Exp. Station, New Orleans, LA.

Skorupa, J. P. and R. W. McFarlane. 1976. Seasonal variation in foraging territory of redcockaded woodpeckers. Wilson Bull. 88: 281-289.

Sokal, R. R. and F. J. Rohlf. 1981. Biometry. Freeman and Company, NY, USA. 859 pp.

Speight, M. C. D. 1989. Life in dead trees- a neglected part of European wildlife heritage. Environ. Cons. 16: 354-356.

Tschinkel, W. R. 2002. The natural history of the arboreal ant, Crematogaster ashmeadi. J. Insect Sci. 2: 1-15.

Tschinkel, W. R. and C. A. Hess. 1999. Arboreal ant community of a pine forest in northern Florida. Ann. Entomol. Soc. Am. 92: 63-76.

Workman, S. W. and K. W. McLeod. 1990. Vegetation of the Savannah River Site: Major community types. Savannah River Ecology Laboratory, National Environmental Research Park Program.

Zarnowitz, J. E. and D. A. Manuwal. 1985. The effects of forest management on cavity-nesting birds in northwestern Washington. J. Wildl. Manage. 49: 255-263. 